\title{
Marital or Civil Status Not Disclosed
}

National Cancer Institute

\section{Source}

National Cancer Institute. Marital or Civil Status Not Disclosed. NCI Thesaurus. Code C150742.

An indication that the marital or civil status of a relationship has not been disclosed. 